Available online on 15.06 .2020 at http://jddtonline.info
Open Access to Pharmaceutical and Medical Research
(c) 2011-18, publisher and licensee JDDT, This is an Open Access article which permits
unrestricted non-commercial use, provided the original work is properly cited

Open Access

Research Article

\title{
Public's Knowledge and Beliefs towards Universal Safety Precautions during COVID-19 Pandemic in Nepal: A web-based Cross-Sectional Study
}

\author{
Deependra Prasad Sarraf ${ }^{*}$, Pramendra Prasad Gupta ${ }^{2}$, Shashi Keshwar ${ }^{3}$ \\ ${ }^{1}$ Associate Professor, Department of Clinical Pharmacology and Therapeutics, B.P. Koirala Institute of Health Sciences, Dharan, Nepal \\ ${ }^{2}$ Associate Professor, Department of General Practice and Emergency Medicine, B.P. Koirala Institute of Health Sciences, Dharan, Nepal \\ ${ }^{3}$ Assistant Professor, Department of Oral Pathology, College of Dental Surgery, B.P. Koirala Institute of Health Sciences, Dharan, Nepal
}

\section{ABSTRACT}

Background: Coronavirus disease (COVID-19) has been declared as a global pandemic. In the absence of vaccines or specific drugs for COVID19 , a better understanding and implementation of universal safety precautions is essential for the prevention of COVID-19 virus infection globally. People's adherence to the universal precautions safety measures against COVID-19 is essential which is largely affected by their knowledge and belief.
\end{abstract}

Objectives: To assess the public's knowledge and belief toward the universal safety precautions during COVID-19 pandemic.

Materials and Methods: A cross-sectional web-based online survey was conducted in general public in Nepal during April, 2020. A selfdesigned questionnaire was prepared using Google forms via docs.google.com/forms for the collection of the data. The study participants were grouped into two categories according to their level of knowledge: excellent (score $80 \%$ and above) and average (score less than 80\%). Descriptive statistics mean, frequency and percentage were used to analyze the data.

Results: Out of 228, majority were male (90.4\%) and aged 36-45 years (36\%). Mean knowledge score was $4.68 \pm 1.41$. Most of them (57.9\%) had average knowledge. Average of the correct responses in the knowledge and belief domain were found to be $66.9 \%$ and $71.2 \%$ respectively. Majority of the public (55.3\%) believed that home-made alcohol-based hand sanitizer is equally effective to factory-made standard sanitizer against COVID-19 virus.

Conclusion: Knowledge toward universal safety precautions against COVID-19 were average among the majority of the public. There was gap between knowledge and belief domain. There is an unmet need for long term educational interventions among the public regarding the preventive methods against COVID-19.

Keywords: Knowledge; Belief; COVID-19; Nepal; Public; Universal safety precautions.

Article Info: Received 23 March 2020; Review Completed 22 May 2020; Accepted 04 June 2020; Available online 15 June 2020

Cite this article as:

Sarraf DP, Gupta PP, Keshwar S, Public's Knowledge and Beliefs towards Universal Safety Precautions during COVID-19 Pandemic in Nepal: A web-based Cross-Sectional Study, Journal of Drug Delivery and Therapeutics. 2020; 10(3-s):133141 http://dx.doi.org/10.22270/jddt.v10i3-s.4175

\section{*Address for Correspondence:}

Dr. Deependra Prasad Sarraf, Associate Professor, Department of Clinical Pharmacology and Therapeutics, B.P. Koirala Institute of Health Sciences, Dharan, Nepal; Email: deependraprasadsarraf@gmail.com

\section{INTRODUCTION}

Coronavirus disease (COVID-19) is an infectious disease caused by severe acute respiratory syndrome coronavirus 2 and has been declared as a global pandemic. The virus is highly contagious and transmitted from person-to-person primarily through inhalation of aerosols of saliva or discharge from the nose when an infected person coughs or sneezes. ${ }^{1,2}$ The mean incubation period of COVID-19 is estimated to be 3-7 days (range 2-14 days). ${ }^{3}$ As per of $20^{\text {th }}$ May, 2020, there were 4,761,559 confirmed cases and 317529 deaths worldwide due to COVID-19.4 Most people ISSN: 2250-1177 infected with the COVID-19 virus experience mild to moderate respiratory illness and recover without requiring special treatment. However, older people and those with underlying medical problems like cardiovascular disease, diabetes, chronic respiratory disease and cancer are more likely to develop serious illness. ${ }^{1}$ To date, there is no specific antiviral treatment for COVID-19 and no vaccine is available. Its treatment is symptomatic. Mechanical ventilation may be necessary in cases of respiratory failure refractory to oxygen therapy. People with mild symptoms who are otherwise healthy should manage their symptoms at home. ${ }^{5}$ Preventive 
measures are the current strategy to limit the spread of cases. The best way to prevent and slow down transmission is to be well informed about the virus, the signs and symptoms, how it spreads and its preventive measures.

Nepal is a landlocked country and shares a 1,414 kilometers border with China in the North and 1,800-km open border with India in the East, West and South. It is one of the least developed country in South-East Asia and most densely populated country. As education, health care and sanitation metrics are poor in Nepal, it is considered as one of the highest risk zone for COVID-19 pandemic and also one of the least prepared. The first case of COVID-19 was detected in Nepal on January 24, 2020.6 As of 20th May 2020, there were 427 confirmed cases of COVID-19 and 2 deaths in Nepal. ${ }^{7}$ Considering the risk of COVID-19 transmission, the government of Nepal has initiated various preventive measures. To date, the whole country is in lock-down since March 24, 2020, where people are asked stay at home except for emergency reasons. ${ }^{8}$

Prevention is better than treatment and it fits COVID-19 pandemic. In the absence of vaccines or specific drugs for COVID-19, a better understanding and implementation of universal safety precautions is essential for the prevention of COVID-19 virus infection globally. ${ }^{3}$ The measures for prevention of person-to-person transmission include regular hand washing with soap and water, social distancing of 1 meter, wearing face mask and covering mouth and nose while coughing or sneezing. ${ }^{9}$ As knowledge is the power, people's adherence to the universal precautions safety measures against COVID-19 is essential which is largely affected by their knowledge and belief.10,11 The general public may have less knowledge and belief toward safety precautions related to COVID-19.12 A poor understanding of the universal safety precautions among public may result in delayed identification and rapid spread of the infection. Public armed with sufficient knowledge and belief may protect themselves, their loved ones and communities during the COVID-19 pandemic. It will also lead to change in behavior. The objective of the study was to assess the public's knowledge and belief toward the universal safety precautions during COVID-19 pandemic. The study would help to determine knowledge gaps to be addressed in public health awareness campaigns.

\section{MATERIALS AND METHODS}

A cross-sectional web-based online survey was conducted in general public in Nepal during April, 2020. Public aged 18 years and above and with the ability to read and write were enrolled. A non-probability sampling method was used. The sample size was calculated using a margin of error of $5 \%$, a confidence interval of $95 \%$, an expected response rate of $70 \%$ to most of the main questions and $10 \%$ non-responder. The minimum sample size estimated for the study was 207. A self-designed questionnaire was used to collect the relevant data (Appendix 1). It has been prepared based on relevant literature. ${ }^{13,14}$ It was adapted with some modifications to the local context. The questionnaire consisted of sociodemographic data, knowledge (7 items) and belief (10 items) sections related to universal safety precautions like personal hygiene, proper handwashing, use of face masks and social distancing techniques such as quarantine and isolation. All questions were close-ended and having one correct answer and three incorrect answer. A scoring system was applied to assess the level of knowledge of each participant: 1 point was given for each correct answer and zero for incorrect answer. Total knowledge score was 7. The study participants were grouped into two categories according to their level of knowledge: excellent (score 80\% and above) and average (score less than $80 \%$ ). ${ }^{15}$ Gender, age group, residence, educational qualification and occupation were the independent variables and knowledge and belief were the dependent variables.

The questionnaire was prepared in English, then translated to Nepali language and again back-translated to English by another independent translator and the content was reviewed by the research team and the subject experts for relevance, simplicity and internal consistency. The questionnaire was prepared using Google forms via docs.google.com/forms. The Google Form link to the questionnaire was sent to the enrolled participants via social media platforms like Facebook and WhatsApp. Upon clicking on the link, it assured the confidentiality of data, informed the public of the study objective and stated that the study participation was purely voluntary. No incentive was given. Only the principal investigator had access to the data and no personal details (e-mail address, phone number, name, etc.) were collected. Its reliability and validity were confirmed by sending the questionnaire to the three subject experts. A pilot testing was also conducted in 20 public to ensure face validity, comprehension and feasibility. The Cronbach's alpha reliability coefficient was found to be 0.79 which was considered satisfactory for this study. The pilot study responses were excluded from the main analysis. Due to the country's lockdown at the time of data collection, ethical clearance could not be obtained; however, the study was performed following the Declaration of Helsinki as revised in 2013. ${ }^{16}$ This study was conducted and reported according to the Checklist for Reporting Results of Internet E-Surveys guidelines. ${ }^{17}$

The filled questionnaires were extracted from the Google Forms and exported to Microsoft Excel 2010. Descriptive statistics frequency and percentage were used to analyze the data. The data were presented as tables. The data analyses were performed using Statistical Package for the Social Sciences (SPSS) software, version 22.

\section{RESULTS}

The Google form was sent to 450 participants and a total of 228 responded giving the response rate of $50.7 \%$. Majority were male (90.4\%) and aged $36-45$ years (36\%). Most of them had completed bachelor degree (50.9\%) and had private job (42.1\%). One hundred and fifty participants (65.8\%) were from Province 2 (Table 1). 
Table1: Sociodemographic characteristics of the participants $(n=228)$

\begin{tabular}{|c|c|c|c|}
\hline \multicolumn{2}{|c|}{ Variables } & Frequency & Percentage \\
\hline \multirow[t]{2}{*}{ Gender } & Male & 206 & 90.4 \\
\hline & Female & 22 & 9.6 \\
\hline \multirow{6}{*}{$\begin{array}{ll}\text { Age } & \text { group } \\
\text { (years) } & \end{array}$} & $18-25$ & 30 & 13.2 \\
\hline & $26-35$ & 64 & 28.1 \\
\hline & $36-45$ & 82 & 36.0 \\
\hline & $46-55$ & 28 & 12.3 \\
\hline & $56-65$ & 21 & 9.2 \\
\hline & $>65$ & 3 & 1.3 \\
\hline \multirow[t]{5}{*}{ Residence } & Province 1 & 42 & 18.4 \\
\hline & Province 2 & 150 & 65.8 \\
\hline & Province 3 & 30 & 13.2 \\
\hline & Province 5 & 4 & 1.8 \\
\hline & Province 7 & 2 & 0.9 \\
\hline \multirow{5}{*}{$\begin{array}{l}\text { Educational } \\
\text { status }\end{array}$} & Primary & 2 & 0.9 \\
\hline & Secondary & 16 & 7.0 \\
\hline & Intermediate & 50 & 21.9 \\
\hline & Bachelor degree & 116 & 50.9 \\
\hline & Master degree & 44 & 19.3 \\
\hline \multirow{7}{*}{ Occupation } & Unemployed & 8 & 3.5 \\
\hline & Farmer & 4 & 1.8 \\
\hline & Housewife & 8 & 3.5 \\
\hline & Private job & 96 & 42.1 \\
\hline & Government job & 56 & 24.6 \\
\hline & Student & 8 & 3.5 \\
\hline & Business & 48 & 21.1 \\
\hline
\end{tabular}

Table 2 shows the knowledge of the public towards universal safety precautions during COVID-19 pandemic Mean knowledge score of the participants was $4.68 \pm 1.413$ [95\% CI 4.50-4.87]. Majority of the participants (57.9\%) had scored less than $80 \%$ of total knowledge score and were considered to have average knowledge. Out of 228 participants, $88.6 \%$ knew the recommended ideal length of time to wash hands for prevention of spread of COVID-19 infection. Only $48.2 \%$ participants knew the ideal strength of the alcohol that a hand-sanitizer should contain to be used during outbreaks of COVID-19 virus. Only $60.5 \%$ of the participants knew the ideal distance to be maintained as part of social distancing measures during the COVID-19 pandemic. $57 \%$ and $66.7 \%$ of the participants knew the quarantine and isolation procedures that are usually followed during COVID-19 pandemic respectively. Only $56.1 \%$ knew the type of face mask that is considered as the ideal protection against COVID-19 virus. Overall average of the correct responses in the knowledge domain by the participants was found to be $66.9 \%$.

Table 2: Knowledge of public toward the universal safety precautions related to COVID-19 (n=228)

\begin{tabular}{|c|c|c|c|c|}
\hline \multirow[t]{2}{*}{ S.N. } & \multirow[t]{2}{*}{ Variables } & \multirow{2}{*}{$\begin{array}{l}\text { Correct } \\
\text { answer }\end{array}$} & \multicolumn{2}{|c|}{ Correct response } \\
\hline & & & Frequency & Percentage \\
\hline 1. & $\begin{array}{l}\text { What is the recommended ideal length of time to wash hands for } \\
\text { prevention of spread of corona virus? }\end{array}$ & 20 seconds & 202 & 88.6 \\
\hline 2. & $\begin{array}{l}\text { What is the recommended minimum strength of alcohol that a } \\
\text { hand-sanitizer should contain for corona virus? }\end{array}$ & $60 \%$ & 110 & 48.2 \\
\hline 3. & $\begin{array}{l}\text { What is the recommended ideal (social) distance to be maintained } \\
\text { in preventing the spread of coronavirus? }\end{array}$ & 1meter & 138 & 60.5 \\
\hline 4. & $\begin{array}{l}\text { During outbreak of corona virus, quarantine is a procedure usually } \\
\text { followed by: }\end{array}$ & $\begin{array}{l}\text { Suspected } \\
\text { cases }\end{array}$ & 130 & 57.0 \\
\hline 5. & $\begin{array}{l}\text { During outbreak of corona virus, isolation is a procedure usually } \\
\text { followed by: }\end{array}$ & $\begin{array}{l}\text { Confirmed } \\
\text { cases }\end{array}$ & 152 & 66.7 \\
\hline 6. & $\begin{array}{l}\text { During outbreak of corona virus, self-isolation period in case of } \\
\text { close-contact is: }\end{array}$ & 14 days & 208 & 91.2 \\
\hline 7. & $\begin{array}{l}\text { During outbreak of corona virus, which type of face mask is } \\
\text { considered as the ideally protective }\end{array}$ & N-95 mask & 128 & 56.1 \\
\hline
\end{tabular}


Table 3 represents the beliefs of the participants towards universal safety precautions during COVID-19 pandemic. Out of 228 participants, $55.3 \%$ believed that home-made alcoholbased hand sanitizer is equally effective to factory-made standard sanitizer against COVID-19 virus. Majority of the participants $(93.9 \%)$ were aware that maintaining good personal hygiene and being socially responsible would prevent the spread of COVID-19 virus. (Table 3). The overall average of the correct responses in the belief domain by the participants was found to be $71.2 \%$.

Table 3: Beliefs of public towards universal safety precautions against COVID-19 (n=228)

\begin{tabular}{|c|c|c|c|c|}
\hline S.N. & Variables & Responses & Frequency & Percentage \\
\hline \multirow[t]{3}{*}{1.} & \multirow{3}{*}{$\begin{array}{l}\text { Home-made alcohol based hand sanitizer is equally } \\
\text { effective to factory-made sanitizer against COVID-19 } \\
\text { virus. }\end{array}$} & Agree & 126 & 55.3 \\
\hline & & Disagree & 78 & 34.2 \\
\hline & & Not sure & 24 & 10.5 \\
\hline \multirow[t]{3}{*}{2.} & \multirow{3}{*}{$\begin{array}{l}\text { Soap with water is equally effective to alcohol-based } \\
\text { sanitizer against COVID-19 virus. }\end{array}$} & Agree & 152 & 66.7 \\
\hline & & Disagree & 56 & 24.6 \\
\hline & & Not sure & 20 & 8.8 \\
\hline \multirow[t]{3}{*}{3.} & \multirow{3}{*}{$\begin{array}{l}\text { Maintain a good personal hygiene and being socially } \\
\text { responsible would prevent the spread of COVID-19 } \\
\text { virus. }\end{array}$} & Agree & 214 & 93.9 \\
\hline & & Disagree & 6 & 2.6 \\
\hline & & Not sure & 8 & 3.5 \\
\hline \multirow[t]{3}{*}{4.} & \multirow{3}{*}{$\begin{array}{l}\text { Washing hand frequently using soap or sanitizer would } \\
\text { prevent the spread of COVID-19 virus. }\end{array}$} & Agree & 199 & 87.3 \\
\hline & & Disagree & 16 & 7 \\
\hline & & Not sure & 13 & 5.7 \\
\hline \multirow[t]{3}{*}{5.} & \multirow{3}{*}{$\begin{array}{l}\text { Avoiding handshaking behavior would prevent the } \\
\text { spread of COVID-19. }\end{array}$} & Agree & 166 & 73.8 \\
\hline & & Disagree & 43 & 18.9 \\
\hline & & Not sure & 19 & 8.3 \\
\hline \multirow[t]{3}{*}{6.} & \multirow{3}{*}{$\begin{array}{l}\text { Avoiding placing fingers into eyes, nose and mouth } \\
\text { would prevent the spread of COVID- } 19 \text {. }\end{array}$} & Agree & 160 & 70.2 \\
\hline & & Disagree & 40 & 17.5 \\
\hline & & Not sure & 28 & 12.3 \\
\hline \multirow[t]{3}{*}{7.} & \multirow{3}{*}{$\begin{array}{l}\text { Coughing and sneezing into the elbow or within the } \\
\text { clothing is a good practice in preventing the spread of } \\
\text { COVID-19 }\end{array}$} & Agree & 180 & 80.3 \\
\hline & & Disagree & 25 & 11 \\
\hline & & Not sure & 20 & 8.8 \\
\hline \multirow[t]{3}{*}{8.} & \multirow{3}{*}{$\begin{array}{l}\text { Limiting eating and sharing food with colleagues and } \\
\text { friends would prevent the spread of COVID- } 19 .\end{array}$} & Agree & 154 & 67.5 \\
\hline & & Disagree & 67 & 29.4 \\
\hline & & Not sure & 7 & 3.1 \\
\hline \multirow[t]{3}{*}{9.} & \multirow{3}{*}{$\begin{array}{l}\text { Following social distancing measure and avoiding } \\
\text { crowded places would limit the spread of COVID-19. }\end{array}$} & Agree & 144 & 63.2 \\
\hline & & Disagree & 72 & 31.6 \\
\hline & & Not sure & 12 & 5.3 \\
\hline \multirow[t]{3}{*}{10.} & \multirow{3}{*}{$\begin{array}{l}\text { Staying at home would play a significant role in } \\
\text { preventing the spread of COVID- } 19 \text {. }\end{array}$} & Agree & 130 & 57.0 \\
\hline & & Disagree & 75 & 32.9 \\
\hline & & Not sure & 23 & 10.1 \\
\hline
\end{tabular}

\section{DISCUSSION}

This web-based cross-sectional study has provided the baseline data to the concerned local and national government for making appropriate educational measures to target the public that ultimately helps to improve their knowledge and belief toward COVID-19 pandemic. Our study findings highlight that most of the pubic had average knowledge toward universal precautions during COVID-19 pandemic; however, there was a gap between knowledge and belief. Two out of three public had given correct responses in the knowledge domain. A lower response rate $(63 \%)$ was reported by Sai Krishna Gudi et al.13 However, the overall correct rate of the knowledge domain was $90 \%$ in a Chinese study. ${ }^{10}$ Similarly, more than two third of the public gave the correct responses in the belief domain in our study. A higher rate of correct response (83\%) toward belief domain had been reported by an Indian study. ${ }^{13}$ 
Maintaining personal hygiene is an essential practice to be protected during COVID-19 pandemic. The most critical measure for reducing the risk of person-to-person transmission of microorganism is hand hygiene.18 COVID-19 virus can persist on surfaces for a few hours or up to several days, depending on the type of surface, the temperature or the humidity of the environment. ${ }^{19}$ Patients with COVID-19 can spread the infection prior to symptom presentation, during the symptomatic course and clinical recovery period. ${ }^{20}$ Therefore, hand washing for at least 20 seconds with plain soap and water after visiting public spaces or touching any other surfaces is the best way to prevent the spread of infections and decrease the risk of getting COVID19. In our study, most of the participants believed that washing hand frequently using soap or sanitizer would prevent the spread of COVID-19 virus and also knew the recommended ideal length of time to wash hands for prevention of spread of COVID-19 infection; however, more than half of them did not know the ideal strength of the alcohol that a hand-sanitizer should contain to be used during COVID-19 pandemic. Similarly, half of them did not believe or were not sure that that home-made alcohol based hand sanitizer is equally effective to factory-made standard sanitizer against COVID-19 virus. Hand sanitizer with at least $60 \%$ of ethanol is recommended. ${ }^{21}$ Use of alcohol-based hand sanitizer is a simple and effective way to prevent the spread of COVID-19 virus. It is the alcohol which attacks and destroys the envelope protein that surrounds coronaviruses. ${ }^{21}$ Its government's duty to educate the public regarding this issue and make them confident that homemade alcohol based hand sanitizer is equally effective to factory-made standard sanitizer during COVID-19 pandemic.

Although the majority of the participants believed that maintaining a good personal hygiene and being socially responsible would prevent the spread of COVID-19 virus, upto two-fifth of them did not know the ideal social distance to be maintained as part of social distancing measures during the COVID-19 pandemic. Social distancing is a technique where actions are taken to reduce the frequency of contacts and to maintain a proper distance between individuals in order to limit the transmission of COVID-19.22 Different countries have different minimum distances which they advise their citizens to maintain. This varies from 1 meter as advised by the World Health Organization (WHO), Singapore and Hong Kong to 1.5 meter in Australia. The USA advises 1.8 meter and the UK, Ireland and New Zealand favor 2 meter. ${ }^{23}$ In Nepal, the recommended minimum safe social distance is 1 meter.

Majority of the participants knew the self-isolation period correctly; however, nearly half of them did not know the quarantine procedures that are usually followed during COVID-19 pandemic. Similarly, one-third of the participants did not know isolation procedures that are usually followed during COVID-19 pandemic. Quarantine is considered as one of the effective methods in controlling communicable outbreaks and pandemics such as COVID-19 at a community level. It is for people or groups who don't have symptoms but were thought to be exposed to the sickness and at high risk of getting COVID-19. The movement of a person is restricted to the home or a designated facility. ${ }^{24}$ Isolation is an act of separating the ill-persons with COVID-19 from a noninfected person to reduce the spread to others in community. ${ }^{25}$ These procedures keep infected people away from healthy people to prevent the sickness from spreading unknowingly to anyone.

Nearly half of the participants did not know the type of face mask that is considered as the ideal protection against COVID-19 virus. In contrast, higher percentage of the public knew the ideal face-mask protective against COVID-19 virus. ${ }^{13} \mathrm{~N}-95$ masks are the ideal mask as it prevents $95 \%$ of the droplets from entering the nose. ${ }^{26}$ However, such masks are expensive and hence reserved for healthcare professionals only and general public can use homemade face mask (multi-layered) or surgical mask that must cover both nose and mouth as per the guidelines. ${ }^{27}$ Routine wearing of face masks by everyone would probably intercept the transmission link of COVID-19 in the community. Face masks should be washed routinely with soap and water or laundry detergent to prevent contamination. ${ }^{28}$ Improper use of face masks, such as not changing disposable masks, could jeopardize the protective effect and even increase the risk of infection. ${ }^{29}$ However, the use of a face mask alone is insufficient to provide an adequate level of protection and other measures like hand washing and safe social distancing should also be adopted. ${ }^{30}$

COVID-19 is a respiratory infection and the virus spreads through respiratory droplets after an infected person coughs or sneezes. It is also transmitted by touching surfaces that have the virus on them, such as handrails, telephones, or doorknobs etc. Avoiding handshaking when greeting others is highly recommended for all public. We should also avoid touching our eyes, nose, and mouth with unwashed hands, because contaminated hands can transfer virus to these areas and make us sick. If we are sneezing or coughing, we should cover our mouth and dispose of tissues after used once. ${ }^{31}$ Our study showed that one-fifth of the public were either disagree or not sure toward the fact that avoiding handshaking behavior and coughing and sneezing into the elbow or within the clothing are good practices for the prevention of the spread of COVID-19. One out of three public did not believe that following social distancing measure and avoiding crowded places, avoiding placing fingers into eyes, nose and mouth, staying at home and limiting eating and sharing food with the colleagues and friends would help to limit the spread of COVID-19. To fill the gap in the knowledge and belief toward universal safety precautions during COVID-19 pandemic, there is unmet need for educational interventions among the general public in Nepal. Certain steps such as sending alerts, disease updates, figures \& facts and precautionary measures regarding the outbreak through mobile message services or newspapers, radio and television should be re-emphasized to inform the public. Timely implementation of these universal safety measures in the community would significantly prevent the spread of COVID-19. Educational programs and awareness campaigns conducted by health care professional also might be effective.

\section{LIMITATIONS}

Our study has some limitations. The study also had a low response rate and this might limit the generalization of the study findings to whole country. Being a cross-sectional, causal inferences could not be made and the study findings might be influenced by recall and information bias. Being a web-based study, it might not include the responses from the regions with the restricted access to social media and might be influenced by geographical and coverage bias.

\section{CONCLUSIONS}

Within the limitation of the study, our study concludes that knowledge toward universal safety precautions against COVID-19 were average among the majority of the public. There was gap between knowledge and belief domain. There is an unmet need for long term educational interventions among the public regarding the preventive methods. The government needs to re-emphasize the safety measures to 
increase the knowledge and belief among public so that they can timely implement these habits for the prevention of the spread of COVID-19. The findings of the study could guide the public health authorities and policy makers in making and implementing educational interventions for the public. More attention should be given to utilizing the various social media resources as plateforms for promoting public health education toward universal precautions.

\section{ACKNOWLEDGMENTS}

Authors of this study would like to extend their gratitude towards all the study participants for investing their time, interest and voluntary participation in providing the essential information.

\section{CONFLICT OF INTEREST}

There was no conflict of interest among the authors.

\section{REFERENCES}

1. Health topics: Coronavirus. WHO, Geneva, 2020. [Available at https://www.who.int/health-topics/coronavirus\#tab=tab_1 (Accessed on 14th May, 2020)]

2. Li Q, Guan X, Wu P, Wang X, Zhou L, Tong Y, et al. Early transmission dynamics in Wuhan, China, of novel coronavirusinfected pneumonia. N Engl J Med. 2020; 382:1199-207.

3. Li H, Liu SM, Yu XH, Tang SL, Tang CK. Coronavirus disease 2019 (COVID-19): current status and future perspectives. Int J Antimicrob Agents. 2020;105951.

4. Coronavirus disease (COVID-19) outbreak situation. WHO, 2020, Geneva. [Available at https://www.who.int/emergencies/diseases/novelcoronavirus-2019 (Accessed on 14th May, 2020)]

5. Cascella M, Rajnik M, Cuomo A, et al. Features, Evaluation and Treatment Coronavirus (COVID-19) [Updated 2020 Apr 6]. In: StatPearls [Internet]. Treasure Island (FL): StatPearls Publishing; 2020.

6. Shrestha R, Shrestha S, Khanal P, KC B. Nepal's first case of COVID-19 and public health response. J Travel Med. 2020; 27(3):taaa024.

7. COVID-19 coronavirus pandemic. Worldometer. [Available at https://www.worldometers.info/coronavirus/\#countries (Accessed on 20th May, 2020)

8. Press Release. Ministry of Home Affairs, Government of Nepal, Kathmandu, Nepal, 2020. [Available at http://moha.gov.np/en/post/press-release-31 (Accessed on 20th May, 2020)]

9. Infection Prevention and Control during health care when Novel Coronavirus (nCoV) infection is suspected. World Health Organization: Geneva, 2020.

10. Zhong BL, Luo W, Li HM, et al. Knowledge, attitudes, and practices towards COVID-19 among Chinese residents during the rapid rise period of the COVID-19 outbreak: a quick online cross-sectional survey. Int J Biol Sci. 2020; 16(10):1745-52.

11. Person B, Sy F, Holton K, Govert B, Liang A, National Center for Infectious Diseases SCOT. Fear and stigma: the epidemic within the SARS outbreak. Emerg Infect Dis. 2004; 10:358-63.

12. Wolf MS, Serper M, Opsasnick L, O'Conor RM, Curtis LM, Benavente JY et al. Awareness, Attitudes, and Actions Related to COVID-19 Among Adults With Chronic Conditions at the Onset of the U.S. Outbreak: A Cross-sectional Survey. Ann Intern Med. 2020 Apr 9.

13. Sai Krishna Gudi, Krishna Undela, Rajesh Venkataraman, Uday Venkat Mateti, Manik Chhabra, Sanath Nyamagoud, Komal Krishna Tiwari. Knowledge and Beliefs towards Universal Safety Precautions to flatten the curve during Novel Coronavirus Disease (nCOVID-19) Pandemic among general
Public in India: Explorations from a National Perspective. medRxiv 2020.03.31.20047126.

14. Ali Al-Hazmi, Ibrahim Gosadi, Ali Somily, Sarah Alsubaie, Abdulaziz Bin Saeed. Knowledge, attitude and practice of secondary schools and university students toward Middle East Respiratory Syndrome epidemic in Saudi Arabia: A crosssectional study. Saudi Journal of Biological Sciences. 2018; 25:572-7.

15. Kaliyaperumal K. Guideline for conducting a knowledge, attitude and practice (KAP) study. AECS illumination. 2004; 4:7-9.

16. World Medical Association. World Medical Association Declaration of Helsinki: ethical principles for medical research involving human subjects. JAMA. 2013; 310(20):2191-4.

17. Eysenbach G. Improving the quality of Web surveys: the Checklist for Reporting Results of Internet E-Surveys (CHERRIES). J Med Internet Res 2004; 6(3):e34.

18. Larson EL, Early E, Cloonan P, Sugrue S, Parides M. 2000. An organizational climate intervention associated with increased handwashing and decreased nosocomial infections. Behav Med. 26(1):14-22.

19. Questions and answers on coronaviruses. World Health Organization, Geneva, 2020. [Available at https://www.who.int/news-room/q-a-detail/qacoronaviruses. (Accessed on May 20, 2020)].

20. Kakodkar P, Kaka N, Baig M. A Comprehensive Literature Review on the Clinical Presentation, and Management of the Pandemic Coronavirus Disease 2019 (COVID-19). Cureus. 2020; 12(4): e7560.

21. Hand Hygiene Recommendations. Coronavirus Disease 2019, Centers for Disease control and Prevention, Department of Health and Human Services. USA, 2020. [Available at https://www.cdc.gov/coronavirus/2019-ncov/hcp/handhygiene.html (Accessed on 20th May, 2020) ]

22. Qualls N, Levitt A, Kanade N, Wright-Jegede N, Dopson S, Biggerstaff $\mathrm{M}$, et al. Community Mitigation Guidelines to Prevent Pandemic Influenza - United States, 2017. MMWR Recomm Rep. 2017; 66(1):1-34.

23. Williams N. Social Distancing in the Covid-19 Pandemic. Occup Med (Lond). 2020; kqaa072.

24. Cetron M, Landwirth J. Public health and ethical considerations in planning for quarantine. Yale J Biol Med. 2005; 78(5):329-34.

25. Wilder-Smith A, Freedman DO. Isolation, quarantine, social distancing and community containment: pivotal role for oldstyle public health measures in the novel coronavirus (2019nCoV) outbreak. J Travel Med. 2020; 27(2): taaa020.

26. Szarpak L, Smereka J, Filipiak KJ, Ladny JR, Jaguszewski M. Cloth Masks Versus Medical Masks for COVID-19 Protection [published online ahead of print, 2020 Apr 14]. Cardiol J. 2020.

27. Use of Cloth Face Coverings to Help Slow the Spread of COVID19. CDC, USA, 2020. [Available at https://www.cdc.gov/coronavirus/2019-ncov/preventgetting-sick/diy-cloth-face-coverings.html (Accessed on May 22, 2020)]

28. Desai AN, Aronoff DM. Masks and Coronavirus Disease 2019 (COVID-19) [published online ahead of print, 2020 Apr 17]. JAMA. 2020;

29. Feng S, Shen C, Xia N, Song W, Fan M, Cowling BJ. Rational use of face masks in the COVID-19 pandemic. Lancet Respir Med. 2020; 8(5):434-6.

30. Advice on the use of masks the community, during home care and in health care settings in the context of the novel coronavirus (2019-nCoV) outbreak. WHO, 2020. [Available at https://www.who.int/docs/defaultsource/documents/advice-on-the-use-of-masks-2019ncov.pdf]

31. Desai AN, Patel P. Stopping the Spread of COVID-19 [published online ahead of print, 2020 Mar 20]. JAMA. 2020 
Appendix 1 (Proforma):

Public's knowledge and beliefs towards universal safety precautions during COVID-19 Pandemic in Nepal: A web-based cross sectional study

We are interested in understanding the knowledge and beliefs related to the universal safety precautions during COVID-19 pandemic among public. You are asked to answer the questions related to the survey topic. We assure you that the response will be kept confidential. It will take approximately 5 minute to complete the survey.

\section{Consent to participate in the survey:}

By clicking the button below, you acknowledge that your participation in the study is voluntary, you are 18 years of age, and that you are aware that you may choose to terminate your participation in the study at any time and for any reason. Yes/No

\section{(A) Sociodemographic details:}

\section{Age:}

Gender:

Residence:

Occupation:

Education:

\section{(B) Knowledge domain}

1. What is the recommended ideal length of time to wash hands for prevention of spread of corona virus?

a. 10 seconds

b. 20 Seconds

c. 30 Seconds

d. 40 Seconds

e. Do not know

2. What is the recommended minimum strength of alcohol that a hand-sanitizer should contain for corona virus?

a. $40 \%$

b. $50 \%$

c. $60 \%$

d. $65 \%$

e. Do not know

3. What is the recommended ideal (social) distance to be maintained in preventing the spread of coronavirus?

a. 1 meter

b. 2 meter

c. 3 meter

d. Do not know

4. During outbreak of corona virus, quarantine is a procedure usually followed by:

a. Healthy people

b. Everyone

c. Infected people with corona virus

d. Immunocompromised people

e. People who don't have symptoms but were suspected or exposed to coronavirus (People at risk).

f. Do not know

5. During outbreak of corona virus, isolation is a procedure usually followed by:

a. Healthy people

b. Everyone

c. Infected people with corona virus

d. Immunocompromised people 
e. People who don't have symptoms but were suspected or exposed to coronavirus (People at risk).

f. Do not know

6. During outbreak of corona virus, self-isolation period in case of close-contact is:

a. 7 days

b. 14 days

c. 21 days

d. Do not know

7. During outbreak of corona virus, which type of face mask is considered as the ideally protective?

a. N-95 mask

b. Surgical mask

c. Cotton mask

d. Do not know

\section{(C) Beliefs domain}

8. Maintain a good personal hygiene and being socially responsible would prevent the spread of corona virus.

a. Agree

b. Neutral

c. Disagree

9. Home-made alcohol sanitizer is equally effective to factory-made sanitizer against corona virus.

a. Agree

b. Neutral

c. Disagree

10. Washing hand frequently using soap or sanitizer would prevent the spread of corona virus.
a. Agree
b. Neutral
c. Disagree

11. Soap with water is more effective than alcohol-based sanitizer against corona virus.

a. Agree

b. Neutral

c. Disagree

12. Avoiding handshaking behavior would prevent the spread of COVID-19.

a. Agree

b. Neutral

c. Disagree

13. Avoiding placing fingers into eyes, nose and mouth would prevent the spread of COVID-19?

a. Agree

b. Neutral

c. Disagree

14. Coughing and sneezing into the elbow or within the clothing is a good practice in preventing the spread of COVID-19?

a. Agree

b. Neutral

c. Disagree

15. Limiting eating and sharing food with colleagues and friends would prevent the spread of COVID-19?

a. Agree

b. Neutral 
c. Disagree

16. Following social distancing measure and avoiding crowded places would limit the spread of COVID-19?

a. Agree

b. Neutral

c. Disagree

17. Staying at home would play a significant role in preventing the spread of COVID- 19?

a. Agree

b. Neutral

c. Disagree

Thank you for the survey. Have a nice time. 